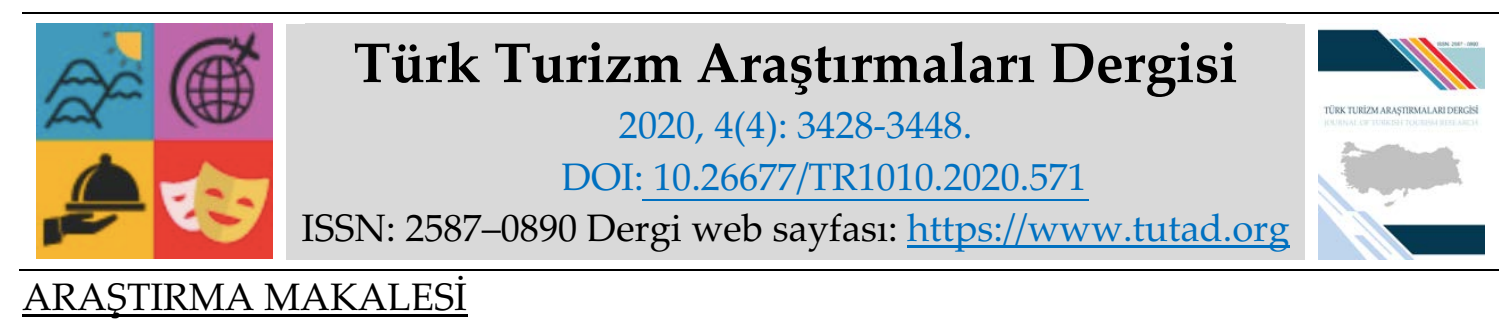

\title{
Mükemmeliyetçiliğin Problem Çözme Becerisine Etkisinde Duygusal Zekânın Aracı Rolü: Turist Rehberlerine Yönelik Bir Uygulama
}

Öğr. Gör. Dr. Ezgi KIRICI TEKELİ, Iğdır Üniversitesi, Iğdır Meslek Yüksekokulu, Iğdır, e-posta: ezgi.kirici@igdir.edu.tr

ORCID: https://orcid.org/0000-0002-1613-8448

Doç. Dr. Aziz Gökhan ÖZKOÇ, Nevşehir HBV Üniversitesi, Turizm Fakültesi, Nevşehir, e-posta: azizgozkoc@nevsehir.edu.tr

ORCID: https://orcid.org/0000-0001-8420-8228

Öz

$\mathrm{Bu}$ araştırmanın amacl, profesyonel turist rehberlerinin mükemmeliyetçi kişilik özelliklerinin problem çözme becerisi üzerine etkisinde duygusal zekânın aracı etkisinin olup olmadığını test etmektir. Araştırmanın teorik kısmında detaylandırılan mükemmeliyetçilik, problem çözme becerisi ve duygusal zekâ etkileşimine dair önermelerin ampirik bazda çözümlenmesi amacıyla, araştırma dahilinde alan araştırması yapılmış ve veriler anket tekniği kullanılarak toplanmıştır. $\mathrm{Bu}$ araştırma kapsamında 410 profesyonel turist rehberi araştırmaya dâhil edilmiş ve araştırma verileri elde edilmiştir. Elde edilen veriler istatistik programlarına yüklenmiş ve uygun analiz teknikleri kullanılarak analiz edilmiştir. Değişkenler arasındaki ilişkide aracılık rolünün olup olmadığı yapısal eşitlik modeli ile ortaya koyulmuştur. Yapılan aracılık testi sonucunda mükemmeliyetçilik ile problem çözme becerisi ilişkisinde duygusal zekânın aracı role sahip olduğu ortaya çıkmıştır. Bootstrapping sonuçlarına göre duygusal zekânın mükemmeliyetçilik ve problem çözme becerisi ilişkisindeki dolaylı etkisinin anlamlı olduğu tespit edilmiştir.

* Bu araştırma, Ezgi KIRICI TEKELİ tarafından Nevşehir HBV Üniversitesi, Sosyal Bilimler Enstitüsü, Turizm İşletmeciliği Ana Bilim Dalı'nda hazırlanan doktora tezinden üretilmiştir.

Anahtar Kelimeler: Mükemmeliyetçilik, Problem Çözme Becerisi, Duygusal Zekâ, Profesyonel Turist Rehberleri.

Makale Gönderme Tarihi: 29.05.2020

Makale Kabul Tarihi: 07.10.2020

\section{Önerilen Atıf:}

Kırıcı Tekeli, E. ve Özkoç, A. G. (2020). Mükemmeliyetçiliğin Problem Çözme Becerisine Etkisinde Duygusal Zekânın Aracı Rolü: Turist Rehberlerine Yönelik Bir Uygulama, Türk Turizm Araştırmaları Dergisi, 4(4): 3428-3448.

(C) 2020 Türk Turizm Araştırmaları Dergisi. 


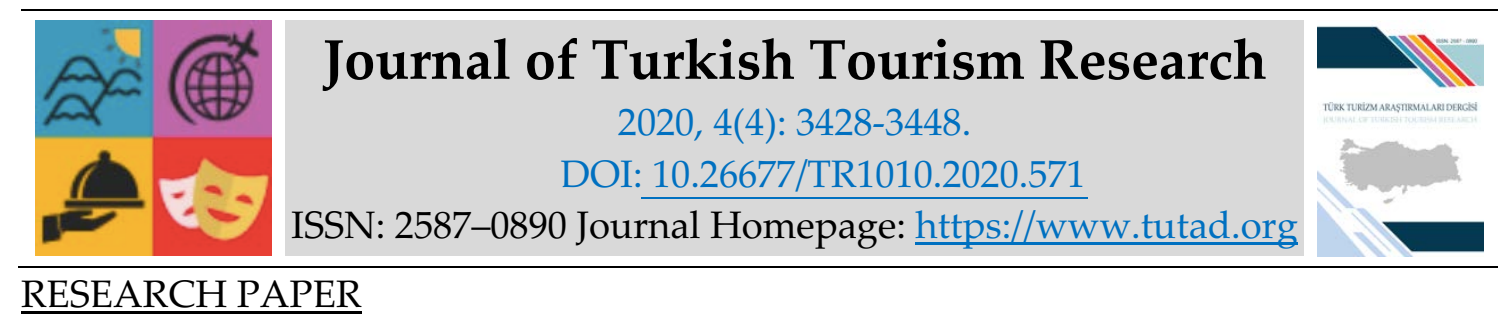

\title{
The Mediating Role of Emotional Intelligence in The Impact of Perfectionism on Problem Solving Skills: An Application for Tourist Guides
}

Dr. Ezgi KIRICI TEKELİ, Iğdır University, Iğdır Vocational School, Iğdır, e-mail: ezgi.kirici@igdir.edu.tr

ORCID: https://orcid.org/0000-0002-1613-8448

Associate Prof. Dr. Aziz Gökhan ÖZKOÇ, Nevşehir HBV University, Faculty of Tourism,

Nevşehir, e-mail: azizgozkoc@nevsehir.edu.tr

ORCID: https://orcid.org/0000-0001-8420-8228

\begin{abstract}
The aim of this study is to test whether emotional intelligence has an intermediary effect on the problem-solving skills of professional tourist guides with perfectionist personality traits. Field research was conducted within the study in order to analyze the suggestions about perfectionism which is detailed in the theoretical part of the study as well as the suggestions regarding the interaction of problem-solving skills and emotional intelligence on an empirical basis by collecting data through survey techniques. Within the scope of this study, 410 professional tourist guides were included in the study and research data were obtained. The obtained data was loaded into statistical programs and analyzed using appropriate analysis techniques. Whether there is an intermediary role in the relationship between the variables has been demonstrated by the structural equation model. As a result of the mediation test, it has been revealed that emotional intelligence has an intermediary role in the relationship between perfectionism and problem-solving skills. According to the results of bootstrapping, the indirect effect of emotional intelligence on perfectionism and problem-solving skills was found to be significant.
\end{abstract}

Keywords: Perfectionism, Problem Solving Skills, Emotional Intelligence, Professional Tourist Guides.

Received: 29.05 .2020

Accepted: 07.10.2020

\footnotetext{
Suggested Citation:

Kırıcı Tekeli, E. and Özkoç, A. G. (2020). The Mediating Role of Emotional Intelligence in The Impact of Perfectionism on Problem Solving Skills: An Application for Tourist Guides, Journal of Turkish Tourism Research, 4(4): 3428-3448.

(C) 2020 Türk Turizm Araştırmaları Dergisi.
} 


\section{Gíriş}

Profesyonel turist rehberleri turizm sektöründe önemli bir yere sahiptir. Bugün gerek sektörün gerekse turistlerin profesyonel turist rehberlerinden beklentileri oldukça yüksektir. Turizm sektöründe, özellikle de seyahat acenteciliği veya tur operatörlüğünde "müşterilere sıfır problem yansıtma" temel hedef olarak kabul edilmektedir (Ahipaşaoğlu, 2006). Problemleri müşterilere yansıtmadan çözme konusunda en etkili olabilecek kişi ise kuşkusuz profesyonel turist rehberleridir. Turistlere gezileri süresince yardımcı olma ve karşılaşılan her türlü problemi seyahat acentesi adına çözme, profesyonel turist rehberlerinin en önemli görevlerinden biridir. Ayrıca problemlerin çözülemediği durumlarda hizmetin bütününe verdiği zararı en aza indirmek, hizmetin düzeltilmesi ve geliştirilmesi için çaba göstermek yine profesyonel turist rehberlerinin görevlerinden biri olmaktadır (Yarcan, 2007). Bu bağlamda profesyonel turist rehberleri karşılaştıkları problemleri çözebilmek ve buna bağlı olarak müşteri memnuniyetini sağlayabilmek için problem çözme becerisine sahip olmalıdır. Problem çözme becerisini profesyonel turist rehberlerinin sahip oldukları mükemmeliyetçilik ve duygusal zekâ düzeyleri etkilemektedir.

Yapılan araştırmanın amacı, profesyonel turist rehberlerinin mükemmeliyetçi kişilik özelliklerinin problem çözme becerisini etkileyip etkilemediğini, eğer etkiliyorsa ne ölçüde etkilediğini ortaya koymaktır. Bununla birlikte mükemmeliyetçiliğin problem çözme becerisi üzerine etkisinde duygusal zekânın aracı etkisinin olup olmadığını test etmek araştırmanın temel amacını oluşturmaktadır. İlgili alanyazın incelendiğinde mükemmeliyetçilik, problem çözme becerisi ve duygusal zekâ değişkenleri ayrı ayrı çalışılmasına rağmen bu üç değişkeni ele alan kapsamlı bir araştırmanın ulusal ve uluslararası alanyazında olmadığı sonucuna ulaşılmıştır. Yapılan araştırmalara bakıldığında profesyonel turist rehberleri üzerine uygulama yapılmaması bir eksiklik olarak varsayılmaktadır. Bu nedenle bu çalışmanın alanyazında önemli bir boşluğu dolduracağ ${ }_{1}$ ve böylelikle profesyonel turist rehberlerine teoride ve pratikte katkı sağlayacağı düşünülmektedir. Bununla birlikte elde edilen sonuçlar, profesyonel turist rehberlerinin bu konularda yaşadıkları sorunları çözebilmesi açısından, bir kaynak niteliğinde olacaktır. Tüm bu bilgiler ışığında, yapılan çalışma alanyazına ve metodolojiye katkılarından dolayı büyük önem arz etmektedir.

\section{KAVRAMSAL ÇERÇEVE}

Araştırmacılar tarafından mükemmeliyetçilikle ilgili çeşitli tanımlar yapılmıştır. Burns (1980), "en iyiyi yapmak için aşırı çaba sarf etme ve aynı zamanda hata yapmaktan kaçınma eğilimi, Flett ve Hewitt (2002) mükemmeliyetçiliği, "kusursuz olma çabası", Antony ve McCabe (2005), "kendisi ve diğerleri için gerçekçi olmayan yüksek standartlara katı bir şekilde bağlı olan bir kişilik özelliği" olarak tanımlamaktadır.

Problem çözme ise "bireyin günlük problemlerle karşılaştığında ne hissettiği ne düşündüğü, nasıl davrandığı ve bunlarla nasıl başa çıktığı" anlamına gelmektedir (Heppner, 1987). Bir başka ifade ile problem çözme, "sorunlu bir durumla başa çıkabilmek için etkili tepki seçenekleri oluşturma ve en uygun olanından birini tercih etmeyi içeren bilişsel ve davranışsal süreç" olarak tanımlanmaktadır (D’Zurilla ve Goldfried, 1971). Anderson (1980) ise problem çözmeyi “bilişsel işlemleri sırasıyla bir hedefe yöneltmek" olarak tanımlamaktadır.

İlgili alanyazın incelendiğinde, mükemmeliyetçilik ile problem çözme becerisi arasındaki ilişkinin çok az çalışıldığı görülmektedir. Yapılan çalışmalar doğrultusunda mükemmeliyetçilik ile problem çözme becerisi arasında negatif bir ilişki (Chang, 2002; Berberena, 2009; Besser vd., 2010) görülürken; pozitif bir ilişkiye de (Flett vd., 1996; Özkara, 2015) rastlamak mümkün 
olmaktadır. Aynı zamanda yapılan çalışmalar doğrudan mükemmeliyetçilik ve problem çözme becerisine yönelik olmayıp, bu değişkenlerle birlikte stres (Flett vd., 1996), intihar (Chang, 1998; Chang, 2002), depresyon (Chang, 2002; Argus ve Thompson, 2007; Besser vd., 2010), psikolojik iyi olma (Toplu, 2013; Özkara, 2015) değişkenlerinin çalışıldığı görülmektedir.

Çalışmanın kavramsal çerçevesini oluşturan diğer bir değişken ise duygusal zekâdır. Duygusal zekâyı tanımlayan ilk bilim insanları olan John D. Mayer ve Peter Salovey kavramı, "kendinin ve başkalarının duygularını izleme, bunlar arasında ayrım yapma ve bu süreçlerden elde ettiği bilgileri düşünce ve davranışlarına yön vermede kullanabilme yeteneği" olarak açıklamaktadırlar (Mayer ve Salovey, 1993).

İlgili alanyazın incelendiğinde, mükemmeliyetçilik ile duygusal zekâ arasındaki ilişkinin araştırıldığı görülmektedir. Yapılan çalışmalar doğrultusunda mükemmeliyetçilik ile duygusal zekâ arasında negatif bir ilişki olduğu saptanmıştır (Smith vd., 2014; Kaya ve Peker, 2016; Çarkıt ve Yalçın, 2018; Kaya ve Birol, 2018; Satıc1, 2018). Ancak olumlu mükemmeliyetçilik ile duygusal zekâ arasında pozitif yönde bir ilişki görülürken, olumsuz mükemmeliyetçilik ile duygusal zekâ arasında negatif yönde bir ilişki söz konusu olmaktadır (Chan, 2009; Eum ve Rice, 2011; Gong vd., 2017; Perrone-McGovern vd., 2017). Duygusal zekâ ile problem çözme becerisi arasında ise pozitif ve anlamlı bir ilişki olduğunu bulan araştırmacılar (İşmen, 2001; Rahim ve Minors, 2003; Güler, 2006; Yerli, 2009; Azeez ve Omolade, 2010; Yılmaz Karabulutlu vd., 2011; Şahin, 2015; Hasnah vd., 2018) olduğu gibi negatif ve anlamsız ilişki bulan araştırmacılara da (Tunca, 2004; Arlı vd., 2011; Nazlı, 2013) rastlamak mümkün olmaktadır.

\section{ARAŞTIRMANIN YÖNTEMI}

Araştırmada profesyonel turist rehberlerinin mükemmeliyetçilik, problem çözme becerisi ve duygusal zekâlarına ilişkin bilgilerin anket ile öğrenilmesi amacıyla nicel yöntem tercih edilmiştir. Anket tekniğinden yararlanarak aynı soru setiyle çok sayıda kişiye ulaşılmış ve elde edilen verilerin analiz edilmesi istatistik programları sayesinde görece kolay olmuştur. Ayrıca yapılan araştırma, açıklayıcı bir araştırma olarak tasarlanmış olup, değişkenler arasındaki nedensonuç ilişkisi ve etkiler ortaya koyulmaya çalışılmıştır.

Mükemmeliyetçilik değişkeni araştırmada dışsal (bağımsız) değişken olarak incelenmekte olup, iki alt boyut yardımıyla analiz edilmiştir. Bu boyutlar; standartlar ve çelişki olarak bilinmektedir. Mükemmeliyetçiliği oluşturan her bir boyuta ilişkin ölçek oluştururken, alanyazın taraması sonucunda 1996 yılında Slaney ve Johnson tarafından geliştirilen 2014 yılında Rice, Richardson ve Tueller tarafından revize edilen "Mükemmeliyetçilik Ölçeği" kullanılmıştır. 2014 yılında revize edilen ölçek 2 boyut olup, 8 ifadeden oluşmaktadır (Rice vd., 2014).

Problem çözme becerisi değişkeni ise araştırmada içsel (bağımlı) değişken olarak incelenmekte olup, üç alt boyut yardımıyla analiz edilmiştir. Bu boyutlar; problem çözme yeteneğine güven, yaklaşma-kaçınma ve kişisel kontrol olarak bilinmektedir. Problem çözme becerisini oluşturan her bir boyuta ilişkin ölçek oluştururken, alanyazın taraması sonucunda 1982 yılında Heppner ve Peterson tarafından geliştirilen "Problem Çözme Becerisi Ölçeği" kullanılmıştır. 1982 yılında geliştirilen ölçek 3 boyut olup, 35 ifadeden oluşmaktadır. Ölçekte 3 ifade dolgu madde olup, puanlama esnasında puanlama dışı tutulmuştur. Bu bağlamda ölçek 32 ifade olarak ele alınmış ve kullanılmıştır (Heppner ve Peterson, 1982).

Duygusal zekâ değişkeni ise araştırmada aracı değişken olarak incelenmekte olup, dört alt boyut yardımıyla analiz edilmiştir. Bu boyutlar; bireysel duygusal değerlendirme, başkalarının duygularını değerlendirme, duyguların kullanımı ve duyguları düzenleme olarak bilinmektedir. Duygusal zekâyı oluşturan her bir boyuta ilişkin ölçek oluştururken, alanyazın taraması 
sonucunda 2002 yılında Wong ve Law tarafından geliştirilen "Duygusal Zekâ Ölçeği" kullanılmıştır. 2002 yılında geliştirilen ölçek 4 boyut olup, 16 ifadeden oluşmaktadır (Ng vd., 2007).

Mükemmeliyetçilik, problem çözme becerisi ve duygusal zekâ ölçekleri Likert-5'li bir ölçektir. Ölçekte yer alan her ifade; "Kesinlikle Katılmıyorum" (1), "Katılmıyorum" (2), "Ne Katılıyorum Ne Katılmıyorum" (3), "Katılıyorum" (4) ve "Kesinlikle Katılıyorum" (5) değerine karşllık gelmektedir.

Ölçekler belirlendikten sonra araştırma modelinin çözümlenmesini sağlayacak, araştırmanın teorik içeriğine uygun araştırma hipotezleri geliştirilmiştir. Hipotezler geliştirilirken alanyazın taraması sonucunda elde edilen bilgilerden yararlanılmış ve değişkenler arasındaki etkiler tespit edilmeye çalışılmıştır. Bu öngörülen sonuçlardan yola çıkarak hipotezlerin içeriği belirlenmiştir. Hipotezler ise şu şekildedir:

Hı: Mükemmeliyetçiliğin problem çözme becerisi üzerinde anlamlı bir etkisi vardır.

$\mathbf{H}_{2}$ : Mükemmeliyetçiliğin duygusal zekâ üzerinde anlamlı bir etkisi vardır.

H3: Duygusal zekânın problem çözme becerisi üzerinde anlamlı bir etkisi vardır.

$\mathbf{H}_{4}$ : Mükemmeliyetçiliğin problem çözme becerisine etkisinde duygusal zekânın aracı rolü vardır.

Belirlenen hipotezlerin test edilmesi için gerekli olan verilerin toplanmasında olasılığa dayalı olmayan örnekleme yöntemlerinden kolayda örnekleme yöntemi kullanılmıştır. Araştırmanın evrenini rehberler odasına bağlı profesyonel turist rehberleri oluşturmaktadır. Türkiye' de toplam 13 tane rehber odası bulunmaktadır. 2019 yılı verilerine göre bu odalara bağlı toplam rehber sayısı 10.918 olarak belirlenmiştir. Ancak 10.918 rehberin 8.195'i eylemli turist rehberi olarak hizmet verirken; 2.723 rehber ise eylemsiz olarak görülmektedir (tureb.org.tr). Bu duruma istinaden, 8.195 kişiden oluşan evren içinde minimum örneklem sayıs1 \%95 güven aralığ ve $\% 5$ örnekleme hatası ile 367 olarak hesaplanmıştır (www.surveysystem.com). Bu araştırma kapsamında 8.195 eylemli rehberin bulunduğu evren içinde 410 rehber araştırmanın örneklemi için belirlenmiştir.

Anketlerin uygulanabilmesi için 21.05.2019 tarih ve 12863 sayılı Etik Kurul İzni Nevşehir Hacı Bektaş Veli Üniversitesi tarafından alınmıştır. Etik Kurul İzni alındıktan sonra 2019 yılının Haziran ayı içerisinde İstanbul'da anketler uygulanmıştır ve anketlerin toplanması yaklaşık olarak bir ay sürmüştür. Toplam 410 adet anket elde edilmiştir. Anketlerin büyük bir çoğunluğu yüz yüze görüşme tekniği ile toplandığı için kayıp veriye rastlanılmamıştır.

Toplanan verilerin nasıl analiz edileceği ve hangi analiz tekniklerinin kullanılacağı araştırma sonuçlarının doğru yorumlanması açısından büyük önem taşımaktadır. Bu araştırmanın sonuçları istatistik programlarına yüklenmiş ve uygun analiz teknikleri kullanılarak analiz edilmiştir. Öncelikli olarak veri setinin normallik varsayımını karşılayıp karşılamadığını değerlendirmek amacıyla üç değişken ve alt boyutlarında yer alan ifadelere ilişkin çarpıklık (skewness) ve basıklık (kurtosis) katsayılarına bakılmıştır. Araştırmanın geçerliliğini ölçmek için keşfedici ve doğrulayıcı faktör analizi yapılmıştır. Faktör analizlerine ek olarak, ölçeklerin birleşim ve ayrışım geçerliliğine de bakılmıştır. Araştırmada kullanılan ölçeklerin güvenilirliğini ölçmek amacıyla içsel tutarlılık analizlerinden biri olan Cronbach alfa olarak da bilinen alfa katsayısına yer verilmiştir. Mükemmeliyetçilik, problem çözme becerisi ve duygusal zekâ arasındaki ilişkiler incelenmiş olup, duygusal zekânın mükemmeliyetçilik ile problem çözme becerisi arasındaki ilişkide aracı etkisinin olup olmadığı yapısal eşitlik modeli ile ortaya koyulmuştur. Bu bağlamda öncelikle mükemmeliyetçilik, problem çözme becerisi ve duygusal zekâ değişkenleri arasındaki doğrudan ve doğrudan olmayan ilişkilerin karşılaştırılmasında yol 
analizi kullanılmıştır. Son olarak ise aracılık testi yapılmıştır. Aracı etkinin anlamlı olup olmadığını test etmek için Bootstrapping yöntemi kullanılmıştır.

Yapılan araştırma kuramsal çerçevede ileri sürülen bilgilerle ve ulaşılabilen alanyazınla sınırlıdır. Yani mükemmeliyetçilik, problem çözme becerisi ve duygusal zekâ değişkenleri arasındaki ilişkiler ve birbirleri üzerindeki etkiler ile sınırlandııılmıştır. Aynı zamanda bu araştırma profesyonel turist rehberleri üzerinde uygulanarak sınırlandırılmıştır. Bununla birlikte 2019 yılı Haziran ayı içerisinde profesyonel turist rehberlerinden anket yöntemiyle elde edilen veriler, araştırma için bir sınırlılık olarak görülmektedir. Yani elde edilen anketler, bir aylık kesitsel bir zaman diliminde toplandığ 1 için bu kısa zaman dilimi araştırmada bir sınırlılık olarak varsayılmaktadır.

\section{ARAŞTIRMANIN BULGULARI}

Belirtilen analizler yapılmadan önce veri setinin normallik varsayımını karşılayıp karşılamadığı kontrol edilmiştir. Yapılan analiz sonucunda, verilerin \pm 1 değer aralığında çarpıklık ve basıklık değerlerine sahip olduğu, veri dağılımının normallik varsayımını karşıladığı görülmektedir. Verilerin normal dağılımlı yapısı belirlendikten sonra, geçerliliğin ve güvenilirliğin belirlenmesi için gerekli analizler yapılmıştır.

Profesyonel turist rehberlerinin mükemmeliyetçiliklerini, problem çözme becerilerini ve duygusal zekâlarını ölçmek amacıyla ölçekler belirlenmiştir. Belirlenen ölçeklerin yapısal geçerliliğini tespit etmek amaciyla temel bileşenler (principal component) analizi ve direct oblimin eksen döndürmesi tekniği kullanılarak keşfedici faktör analizi uygulanmıştır. Keşfedici faktör analizi neticesinde, mükemmeliyetçilik ölçeğine ilişkin Kaiser-Meyer-Olkin (KMO) örneklem yeterlilik değerinin .78; problem çözme becerisi ölçeğine ilişkin KMO değerinin .88 ve duygusal zekâ ölçeğine ilişkin KMO değerinin ise .83 olduğu ve örneklem büyüklüğünün faktör analizi için yeterli olduğu tespit edilmiştir. Bartlett küresellik testinin anlamlı olması $(p<.001)$ maddeler arasındaki korelasyon ilişkilerinin faktör analizi için uygun olduğuna işaret etmektedir. Keşfedici faktör analizinde öz değerlerin 1'den büyük olması durumunda faktörlerin oluşması sağlanmıştır. Keşfedici faktör analizi neticesinde, mükemmeliyetçilik ölçeğine ilişkin iki faktörlü, problem çözme becerisine ilişkin üç faktörlü, duygusal zekâ ölçeğine ilişkin ise dört faktörlü bir sonuç elde edilmiştir. Yamaç serpinti grafiği ve faktörlerin açıkladıkları varyanslar dikkate alınarak ölçeklerin faktör yapılarının uygun olduğu görülmüştür. Ancak problem çözme becerisi ölçeğinden madde çıkartılması gerektiği öngörülmüştür. Bu kapsamda, sekiz madde öngörülenden farklı bir boyuta yüklendiği için, iki madde çapraz yüklenme eğilimi gösterdiği için, bir madde .3'ün altında faktör yüküne sahip olduğu gerekçesiyle, ölçekten toplam 11 maddenin çıkartılmasına karar verilmiştir. Ölçeklere ilişkin KFA sonuçları Tablo 1'de gösterilmektedir.

Tablo 1'de görüldüğü üzere mükemmeliyetçilik ölçeğine ilişkin birinci faktörün \%39,022, ikinci faktörün \%31,370 oranında varyansı açıladığı, faktörlerin toplam varyansının ise \%70,392'sini açıladığ becerisine ilişkin birinci faktörün \%30,438, ikinci faktörün \%10,721, üçüncü faktörün \%9,046 oranında varyansı açıkladığı, faktörlerin toplam varyansının ise \%50,205'ini açıkladığı tespit edilmiştir. Problem Çözme Becerisi ölçeği Heppner ve Peterson (1982) tarafından geliştirilen ve Türkçe'ye uyarlanan bir ölçektir. Uyarlama bir ölçek olmasından dolayı bu araştırmada da olduğu gibi yapılan diğer araştırmalarda ölçekten 3 ile 12 arasında madde çıkartıldığ görülmektedir (Turan, 2010; Kardaş vd., 2014). Son olarak duygusal zekâ ölçeğine ilişkin birinci faktörün $\% 34,356$, ikinci faktörün $\% 12,057$, üçüncü faktörün $\% 11,319$, dördüncü faktörün $\% 8,807$ 
oranında varyansı açıkladığı, faktörlerin toplam varyansının ise \%66,539'unu açıkladığı tespit edilmiştir. Bu sonuçlar, ölçeklerin geçerliliklerine işaret etmektedir.

Tablo 1. Ölçeklere İlişkin KFA Sonuçları

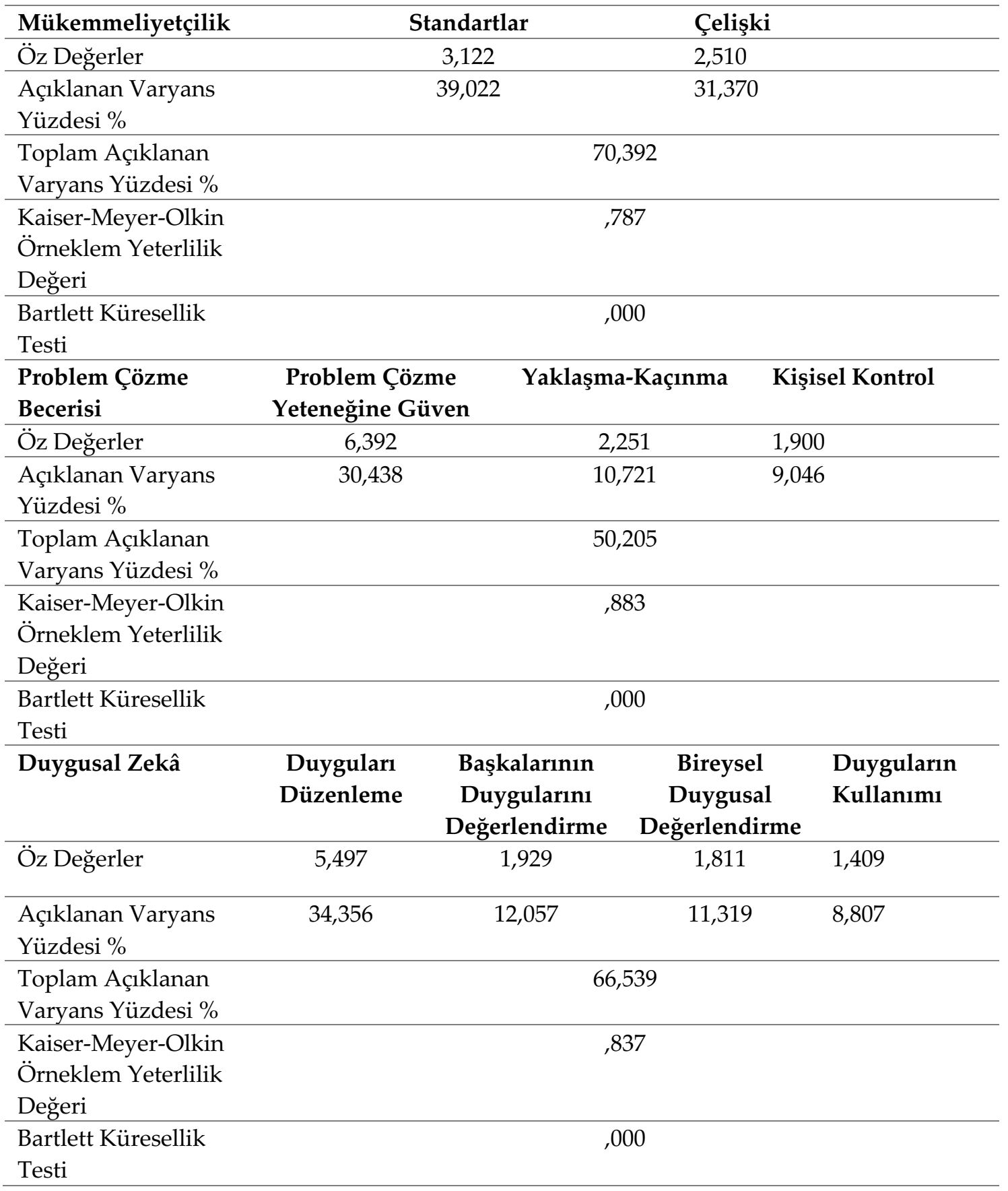

Mükemmeliyetçilik ölçeğinin ikinci düzey çok faktörlü yapısı, problem çözme becerisi ve duygusal zekâ ölçeklerinin birinci düzey çok faktörlü yapısı istatistik programı kullanılarak doğrulayıcı faktör analizi ile test edilmiştir. Verilerin normal dağılım göstermesi nedeniyle maksimum likelihood hesaplama yöntemi kullanılmıştır. 
Tablo 2. Doğrulayıcı Faktör Analizi Sonucu Elde Edilen Uyum İndeksleri

\begin{tabular}{|c|c|c|c|c|c|c|}
\hline \multirow[b]{2}{*}{$\begin{array}{l}\text { Ölçüm (Uyum } \\
\text { İstatistiği) }\end{array}$} & \multicolumn{2}{|c|}{ Mükemmeliyetçilik } & \multicolumn{2}{|c|}{$\begin{array}{l}\text { Problem Çözme } \\
\text { Becerisi }\end{array}$} & \multicolumn{2}{|c|}{ Duygusal Zekâ } \\
\hline & Değerler & Sonuç & Değerler & Sonuç & Değerler & Sonuç \\
\hline$\left(x^{2} / s d\right)$ & 2,809 & İyi Uyum & 2,102 & İyi Uyum & 2,849 & İyi Uyum \\
\hline NFI & 0,970 & İyi Uyum & 0,901 & $\begin{array}{l}\text { Kabul } \\
\text { Edilebilir } \\
\text { Uyum }\end{array}$ & 0,910 & $\begin{array}{l}\text { Kabul } \\
\text { Edilebilir } \\
\text { Uyum }\end{array}$ \\
\hline NNFI(TLI) & 0,968 & İyi Uyum & 0,923 & $\begin{array}{l}\text { Kabul } \\
\text { Edilebilir } \\
\text { Uyum }\end{array}$ & 0,925 & $\begin{array}{l}\text { Kabul } \\
\text { Edilebilir } \\
\text { Uyum }\end{array}$ \\
\hline IFI & 0,981 & İyi Uyum & 0,934 & $\begin{array}{l}\text { Kabul } \\
\text { Edilebilir } \\
\text { Uyum }\end{array}$ & 0,940 & $\begin{array}{l}\text { Kabul } \\
\text { Edilebilir } \\
\text { Uyum }\end{array}$ \\
\hline CFI & 0,981 & İyi Uyum & 0,933 & $\begin{array}{l}\text { Kabul } \\
\text { Edilebilir } \\
\text { Uyum }\end{array}$ & 0,939 & $\begin{array}{l}\text { Kabul } \\
\text { Edilebilir } \\
\text { Uyum }\end{array}$ \\
\hline RMSEA & 0,066 & $\begin{array}{l}\text { Kabul } \\
\text { Edilebilir } \\
\text { Uyum }\end{array}$ & 0,052 & $\begin{array}{l}\text { Kabul } \\
\text { Edilebilir } \\
\text { Uyum }\end{array}$ & 0,067 & $\begin{array}{l}\text { Kabul } \\
\text { Edilebilir } \\
\text { Uyum }\end{array}$ \\
\hline GFI & 0,972 & İyi Uyum & 0,919 & İyi Uyum & 0,924 & İyi Uyum \\
\hline AGFI & 0,941 & İyi Uyum & 0,907 & İyi Uyum & 0,904 & İyi Uyum \\
\hline
\end{tabular}

Doğrulayıcı faktör analizi sonucunda faktör yapılarına ilişkin elde edilen uyum indeks değerlerine Tablo 2'de yer verilmiştir. Analiz sonucunda, değişkenler arası ilişkiler istatistiksel olarak anlamlı bulunmuştur. Doğrulayıcı faktör analizine göre, yapısal eşitlik model sonucu mükemmeliyetçilik ölçeğini oluşturan 8 madde ve 2 alt boyutun ölçek yapısıyla ilişkili olduğu belirlenmiştir. İkincil seviye doğrulayıcı faktör analizi sonuçlarına göre uyum indeks değerleri $(x 2 / \mathrm{sd}=2,809$ ， NFI $=0,970 ， \mathrm{NNFI}(\mathrm{TLI})=0,968 ， \mathrm{IFI}=0,981, \mathrm{CFI}=0,981$ ， RMSEA $=0,066 ， \mathrm{GFI}=0,972$, AGFI $=0,941$ ) önerilen iki faktörlü modelin veri ile uyumlu ve kabul edilebilir olduğunu göstermektedir. Yapısal eşitlik model sonucu problem çözme becerisi ölçeğini oluşturan 21 madde ve 3 alt boyutun ölçek yapısıyla ilişkili olduğu belirlenmiştir. Birincil seviye DFA sonuçlarına göre uyum indeks değerleri $(x 2 / \mathrm{sd}=2,102, \mathrm{NFI}=0,901, \mathrm{NNFI}(\mathrm{TLI})=0,923, \mathrm{IFI}=0,934$, CFI $=0,933$, RMSEA $=0,052, \mathrm{GFI}=0,919$, AGFI $=0,907$ ) önerilen üç faktörlü modelin veri ile uyumlu ve kabul edilebilir olduğunu göstermektedir. Son olarak ise duygusal zekâ ölçeğini oluşturan 16 madde ve 4 alt boyutun yine ölçek yapısıyla ilişkili olduğu belirlenmiştir. Birincil seviye DFA sonuçlarına göre uyum indeks değerleri $(x 2 / s d=2,849, \mathrm{NFI}=0,910, \mathrm{NNFI}(\mathrm{TLI})=0,925$, IFI $=0,940$, CFI=0,939, RMSEA=0,067, GFI=0,924, AGFI=0,904) önerilen dört faktörlü modelin veri ile uyumlu ve kabul edilebilir olduğunu göstermektedir. Bu sonuçlar, mükemmeliyetçilik, problem çözme becerisi ve duygusal zekâ ölçeklerine ilişkin ön görülen kuramsal yapının doğrulandığını belirtmektedir.

Mükemmeliyetçilik ölçeğine ilişkin yapılan doğrulayıcı faktör analizi sonucu elde edilen faktör yükleri ,513 ile ,889 arasında; problem çözme becerisi ölçeğine ilişkin yapılan doğrulayıcı faktör analizi sonucu elde edilen faktör yükleri ,378 ile ,817 arasında ve son olarak duygusal zekâ ölçeğine ilişkin yapılan doğrulayıcı faktör analizi sonucu elde edilen faktör yükleri ,498 ile ,892 arasında değişkenlik göstermektedir. 
Doğrulayıcı faktör analizine ek olarak, araştırmada ele alınan gözlenen değişkenlerin, bağlı oldukları gizil yapıların birer temsilcisi olup olmadıklarını ortaya koyabilmek amacıyla birleşim ve ayrışım geçerliliği hesaplanmıştır (Fornell ve Larcker, 1981). Tablo 3'te birleşim ve ayrışım geçerliliğine ilişkin tüm değerler görülmektedir. Aynı zamanda mükemmeliyetçilik, problem çözme becerisi ve duygusal zekâ ölçeklerine yönelik güvenilirlik analizi yapılmıştır. Bu araştırma kapsamında ölçeklerin güvenilirliklerini ölçmek amacıyla içsel tutarlılık analizinden yararlanılmış olup, ölçeklere ilişkin alfa kat sayısına yer verilmiştir. Tablo 3 'te güvenilirlik analizi sonuçlarını da görmek mümkündür.

Tablo 3. Ölçüm Modellerine İlişkin Birleşim ve Ayrışım Geçerliliği Değerleri ve Ölçeklerin Güvenilirlik Katsayıları

\begin{tabular}{|c|c|c|c|c|c|c|c|}
\hline Faktörler & CR & AVE & MSV & ASV & $\begin{array}{l}\text { AVE'nin } \\
\text { Karekökü }\end{array}$ & $\begin{array}{c}\text { Faktörler Arası } \\
\text { Korelasyon }\end{array}$ & $\begin{array}{c}\text { Cronbach's } \\
\text { Alpha }\end{array}$ \\
\hline $\mathrm{M}$ & & & & & & & 68,4 \\
\hline$S$ & 0,86 & 0,61 & 0,02 & 0,02 & 0,78 & $-0,149$ & 84,6 \\
\hline Ç & 0,84 & 0,58 & 0,02 & 0,02 & 0,76 & & 84,8 \\
\hline PÇB & & & & & & & 87,5 \\
\hline PÇYG & 0,86 & 0,43 & 0,28 & 0,26 & 0,66 & 0,531 & 86,2 \\
\hline $\mathrm{YK}$ & 0,80 & 0,35 & 0,28 & 0,21 & 0,59 & 0,490 & 79,1 \\
\hline KK & 0,80 & 0,45 & 0,24 & 0,19 & 0,67 & 0,369 & 80 \\
\hline DZ & & & & & & & 86,9 \\
\hline BİRDD & 0,83 & 0,56 & 0,15 & 0,14 & 0,75 & 0,355 & 83 \\
\hline BAŞDD & 0,83 & 0,55 & 0,19 & 0,13 & 0,74 & 0,385 & 81,5 \\
\hline DUYKUL & 0,76 & 0,46 & 0,24 & 0,15 & 0,68 & 0,381 & 74,8 \\
\hline DUYDÜZ & 0,88 & 0,65 & 0,24 & 0,19 & 0,80 & $\begin{array}{l}0,270 \\
0,432 \\
0,491\end{array}$ & 88 \\
\hline
\end{tabular}

M=Mükemmeliyetçilik, S=Standartlar, Ç=Çelişki, PÇB=Problem Çözme Becerisi, PÇYG=Problem Çözme Yeteneğine Güven, YK=Yaklaşma-Kaçınma, KK=Kişisel Kontrol, DZ=Duygusal Zekâ, BİRDD=Bireysel Duygusal Değerlendirme, BAŞDD=Başkalarının Duygularını Değerlendirme, DUYKUL=Duyguların Kullanımı, DUYDÜZ=Duyguları Düzenleme.

Tablo 3 incelendiğinde hesaplanan en düşük CR değerinin 0,76; hesaplanan en düşük AVE değerinin ise 0,35 olduğu görülmektedir. AVE değerlerinin 0,50 'den büyük olması beklenirken bazı değerler 0,50'ye yakın çıkmıştır. Ölçüm modeli içerisinde yer alan tüm değişkenlerin birleşim geçerliliğini sağlayabilmesi için gerekli olan değerlerin sağlandığı ve bu değerlerin kabul edilebilir oldukları söylenebilir. Ayrışım geçerliliği için ise MSV ve ASV değerlerinin AVE değerlerinden küçük olması gerekmektedir. Ayrıca AVE değerlerinin kareköklerinin faktörler arası korelasyondan büyük olması beklenmektedir. Tablo 3 incelendiğinde tüm değişkenler için ayrışım geçerliliğinin sağlandığı görülmektedir. Bu sonuçlara göre Tablo 3'teki değerler birleşim ve ayrışım geçerliliği için yeterli ve kabul edilebilirdir (CR $>0,70>A V E>0,50 ; \quad M S V<A V E$; ASV $<$ AVE; AVE'nin Karekökü>Faktörler Arası Korelasyon). Ayrıca mükemmeliyetçilik ölçeğinin güvenilirlik katsayısı, Alpha $(\alpha)=0,68$; problem çözme becerisi ölçeğinin güvenilirlik katsayısı, Alpha $(\alpha)=0,87$; duygusal zekâ ölçeğinin güvenilirlik katsayısı ise Alpha $(\alpha)=0,86$ olarak tespit edilmiştir. Ölçekteki maddeler arasındaki iç tutarlılık değeri kabul edilebilir değer olan 0.60 'tan yüksek olduğu için, araştırmada veri toplama aracı olarak kullanılan ölçeklerin güvenilirlik düzeylerinin yüksek olduğu söylenebilir. 
Geçerlilik ile güvenilirlik analizleri yapıldıktan sonra değişkenler arasındaki nedensel ilişkiler değerlendirilmiştir. Bunun için Şekil 1'de yol analizi sonucuna yer verilmiştir.

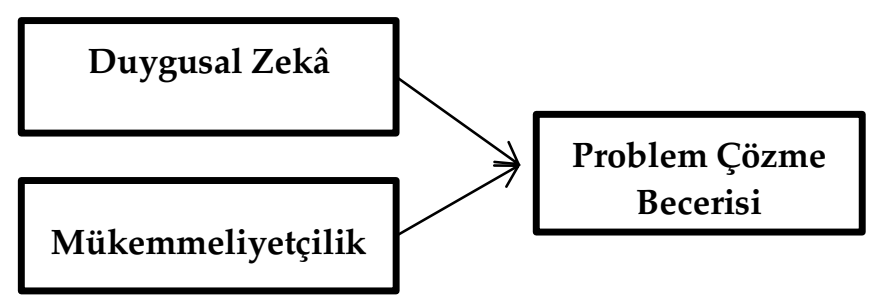

Şekil 1. Gizil Değişkenlerle Yol Analizi Modeli

Gizil değişkenlerle yol analizi sonuçlarına göre uyum indeks değerleri $(x 2 / s d=1,843, \mathrm{NFI}=0,904$, $\mathrm{NNFI}(\mathrm{TLI})=0,907, \mathrm{IFI}=0,905, \mathrm{CFI}=0,905, \mathrm{RMSEA}=0,045, \mathrm{GFI}=0,859$, AGFI $=0,829)$ önerilen modelin veri ile uyumlu ve kabul edilebilir olduğunu göstermektedir. Yani bu sonuçlara göre, kurulan modelin uygun olduğunu söylemek mümkündür.

Modele ilişkin uyum tespit edildikten sonra değişkenler arasındaki ilişkilerin anlamlılığ 1 kontrol edilmiştir. Bazı değişkenler arasındaki yol katsayılarının anlamsız olduğu görülmüştür. Buna bağlı olarak anlamsız olan yol katsayıları modelden çıkartılmıştır. Anlamlılık kontrol edildikten sonra değişkenlere ilişkin Beta değerleri incelenerek dişsal değişkenlerin içsel değişken üzerindeki etkisine bakılmıştır. Tüm değişkenlere ait anlamlılık ve Beta değerleri Tablo 4 'te görülmektedir.

Tablo 4. Değişkenlere İlişkin Yol Katsayıları ve Etki Büyüklükleri

\begin{tabular}{|c|c|c|c|}
\hline Etkilenen $\leftarrow$ Etkileyen & $\mathrm{p}$ & Beta $(\beta)$ & Etki Büyüklüğü \\
\hline $\mathrm{PÇYG} \leftarrow \mathrm{S}$ & $* * *$ & ,166 & Küçük Etki \\
\hline $\mathrm{YK} \leftarrow \mathrm{S}$ & $* * *$ & ,225 & Orta Etki \\
\hline $\mathrm{KK} \leftarrow \mathrm{S}$ & $* * *$ & ,288 & Orta Etki \\
\hline $\mathrm{PÇYG \leftarrow Ç}$ & ,006 &,- 139 & Küçük Etki \\
\hline $\mathrm{YK} \leftarrow \mathrm{C}$ & 106 &,- 091 & - \\
\hline $\mathrm{KK} \leftarrow \mathrm{C}$ & $* * *$ &,- 275 & Orta Etki \\
\hline PÇYG $\leftarrow$ BIIRDD & ,753 & 019 & - \\
\hline $\mathrm{YK} \leftarrow$ BİRDD & ,815 &, 015 & - \\
\hline $\mathrm{KK} \leftarrow \mathrm{BIIRDD}$ & ,381 &,- 056 & - \\
\hline $\mathrm{PÇYG} \leftarrow \mathrm{BAŞDD}$ & $* * *$ & 204 & Orta Etki \\
\hline $\mathrm{YK} \leftarrow \mathrm{BASSDD}$ & ,004 & 191 & Küçük Etki \\
\hline $\mathrm{KK} \leftarrow \mathrm{BAŞDD}$ & 187 &,- 082 & - \\
\hline PÇYG $\leftarrow$ DUYKUL & $* * *$ & ,330 & Orta Etki \\
\hline YK $\leftarrow$ DUYKUL & $* * *$ & ,285 & Orta Etki \\
\hline KK $\leftarrow$ DUYKUL & $* * *$ & 379 & Orta Etki \\
\hline PÇYG $\leftarrow$ DUYDÜZ & ,040 & ,134 & Küçük Etki \\
\hline YK $\leftarrow$ DUYDÜZ & ,075 &,- 130 & - \\
\hline KK $\leftarrow$ DUYDÜZ & ,328 &, 067 & - \\
\hline
\end{tabular}

S=Standartlar, Ç=Çelişki, PÇYG=Problem Çözme Yeteneğine Güven, YK=Yaklaşma-Kaçınma, KK=Kişisel Kontrol, BİRDD=Bireysel Duygusal Değerlendirme, BAŞDD=Başkalarının Duygularını Değerlendirme, DUYKUL=Duyguların Kullanımı, DUYDÜZ=Duyguları Düzenleme. 
Tablo 4'e göre standartlar problem çözme yeteneğine güveni $(p<0,05 ; \beta=166)$, yaklaşmakaçınmayı $(p<0,05 ; \beta=, 225)$ ve kişisel kontrolü $(p<0,05 ; \beta=, 288)$ doğrusal yönde etkilemektedir. Yani standartlardaki bir birimlik değişim problem çözme yeteneğine güvende 0,166 , yaklaşmakaçınmada 0,225 ve kişisel kontrolde 0,288 oranında değişime neden olmaktadır. Çelişki problem çözme yeteneğine güveni $(p<0,05 ; \beta=-, 139)$ ve kişisel kontrolü $(p<0,05 ; \beta=-, 275)$ ters yönde etkilemektedir. Yani çelişkideki bir birimlik değişim problem çözme yeteneğine güvende -0,139 ve kişisel kontrolde $-0,275$ oranında değişime neden olmaktadır. Ancak çelişkinin yaklaşmakaçınma üzerinde istatistiksel olarak anlamlı bir etkisi tespit edilememiştir $(p>0,05)$. Benzer şekilde bireysel duygusal değerlendirmenin problem çözme yeteneğine güven, yaklaşmakaçınma ve kişisel kontrol üzerinde istatistiksel olarak anlamlı bir etkisi tespit edilememiştir $(p>0,05)$. Başkalarının duygularını değerlendirme problem çözme yeteneğine güveni $(p<0,05$; $\beta=, 204)$ ve yaklaşma-kaçınmayı $(p<0,05 ; \beta=, 191)$ doğrusal yönde etkilemektedir. Yani başkalarının duygularını değerlendirmedeki bir birimlik değişim problem çözme yeteneğine güvende 0,204 ve yaklaşma-kaçınmada 0,191 oranında değişime neden olmaktadır. Ancak başkalarının duyguların değerlendirmenin kişisel kontrol üzerinde istatistiksel olarak anlamlı bir etkisi tespit edilememiştir ( $>>0,05)$. Duyguların kullanımı problem çözme yeteneğine güveni $(p<0,05 ; \beta=, 330)$, yaklaşma-kaçınmayı $(p<0,05 ; \beta=, 285)$ ve kişisel kontrolü $(p<0,05 ; \beta=, 379)$ doğrusal yönde etkilemektedir. Yani duyguların kullanımındaki bir birimlik değişim problem çözme yeteneğine güvende 0,330 , yaklaşma-kaçınmada 0,285 ve kişisel kontrolde 0,379 oranında değişime neden olmaktadır. Duyguları düzenleme problem çözme yeteneğine güveni doğrusal yönde etkilerken ( $p<0,05 ; \beta=, 134)$, duyguları düzenlemenin yaklaşma-kaçınma ve kişisel kontrol üzerinde istatistiksel olarak anlamlı bir etkisi tespit edilememiştir $(p>0,05)$. Buna göre duyguları düzenlemedeki bir birimlik değişim problem çözme yeteneğine güvende 0,134 oranında değişime neden olmaktadır.

Etki büyüklükleri değerlendirilirken Kline'ın (2010) önerdiği ölçütler göz önüne alınmıştır. Kline'a (2010) göre yol katsayısı 0,10' dan düşük ise küçük etki, 0,30 dolaylarında ise orta etki, 0,50 ya da daha yüksek ise büyük etki olarak yorumlanabilmektedir. Buna göre standartların problem çözme yeteneğine güven üzerindeki etkisi küçük düzeyde iken, yaklaşma-kaçınma ve kişisel kontrol üzerindeki etkisi orta düzeydedir. Çelişkinin problem çözme yeteneğine güven üzerindeki etkisi küçük düzeyde iken, kişisel kontrol üzerindeki etkisi orta düzeyde görülmektedir. Başkalarının duygularını değerlendirmenin problem çözme yeteneğine güven üzerindeki etkisi orta düzeyde iken, yaklaşma-kaçınma üzerindeki etkisi küçük düzeydedir. Duyguların kullanımının problem çözme yeteneğine güven, yaklaşma-kaçınma ve kişisel kontrol üzerinde orta düzey bir etkisi görülmektedir. Duyguları düzenlemenin problem çözme yeteneğine güven üzerindeki etkisi ise küçük düzeydedir.

Yol analizi yapıldıktan sonra duygusal zekânın aracılık rolü test edilmiştir. Aracılık etkisinin istatistiksel olarak ispatlanmasına ilişkin iki temel yaklaşım bulunmaktadır. Bunlar; geleneksel yaklaşım olarak kabul edilen Baron ve Kenny'nin yaklaşımı ve çağdaş yaklaşım olarak bilinmektedir (Gürbüz, 2019a; Gürbüz, 2019b). Son yıllarda yapılan çalışmalar geleneksel yaklaşıma önemli eleştiriler getirmiştir. Üç farklı hipotezin desteklenmesi neticesinde aracı etkiye karar verilmesi, tam aracı ve kısmi aracı terimlerinin tartışmalı olması, Sobel testinin katı ve güvenilirliği düşük bir test olması geleneksel yaklaşıma getirilen eleştirilerden bazılarıdır. $\mathrm{Bu}$ nedenle araştırma kapsamında çağdaş yaklaşım esas alınmıştır (Hayes, 2018; Gürbüz, 2019a; Gürbüz, 2019b). Genel olarak aracilık (mediation) analizi çalışmalarında üç yöntem kullanılmaktadır. Bunlar regresyon temelli analiz, yapısal eşitlik modellemesini temel alan analiz ve PROCESS makrosu aracılığıyla analiz olarak gruplandırılmaktadır. Bu çalışmada aracı etkinin test edilebilmesi amacıyla yapısal eşitlik modellemesinden (YEM) yararlanılmıştır. 
Çağdaş yaklaşım esas alınarak ve YEM'den yararlanılarak profesyonel turist rehberlerinin mükemmeliyetçilik düzeylerinin problem çözme becerisine etkisinde duygusal zekânın aracı rolü test edilmiştir. Aracı etkiye ilişkin analizlerin yapılabilmesi için iki farklı modelden yararlanılmıştır. Araştırmanın birinci modelinde mükemmeliyetçiliğin problem çözme becerisi üzerinde bir etkisi olup olmadığı test edilmiş olup, model Şekil 2' de gösterilmiştir.

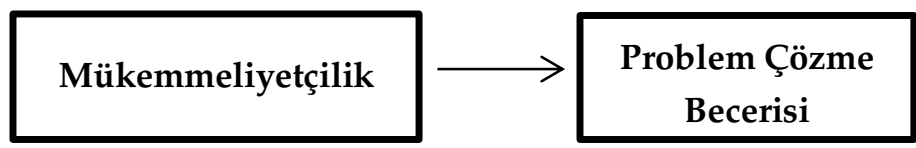

Şekil 2. Aracılık Etkisinin Test Edilmesi İçin Kurulan Birinci Model

Aracılık etkisinin test edilmesi için kurulan birinci modele ilişkin analiz sonuçlarına göre uyum indeks değerleri (x2/sd=2,085, NFI $=0,902$, NNFI(TLI) $=0,907$, IFI $=0,917, \mathrm{CFI}=0,916$, RMSEA $=0,052$, GFI $=0,885$, AGFI $=0,863$ ) önerilen modelin veri ile uyumlu ve kabul edilebilir olduğunu göstermektedir. Yani bu sonuçlara göre, kurulan modelin uygun olduğunu söylemek mümkündür. Dolayısıyla aracılık etkisinin test edilmesi için oluşturulan birinci modelin veri uyumu sağlanmaktadır.

Birinci modele ilişkin uyum tespit edildikten sonra değişkenler arasındaki ilişkilerin anlamlılığ1 kontrol edilmiştir. Anlamlılık kontrol edildikten sonra değişkenlere ilişkin Beta değerleri incelenerek dışsal değişken olan mükemmeliyetçiliğin içsel değişken olan problem çözme becerisi üzerindeki etkisine bakılmıştır. Birinci modele ilişkin anlamlılık ve Beta değerleri Tablo 5 'te görülmektedir.

Tablo 5. Birinci Modele İlişkin Yol Katsayıları ve Etki Büyüklükleri

\begin{tabular}{lccc}
\hline Etkilenen $\leftarrow$ Etkileyen & $\mathbf{p}$ & Beta $(\boldsymbol{\beta})$ & Etki Büyüklüğ̈̈ \\
\hline $\mathrm{PÇYG \leftarrow S}$ & $* * *$ &, 341 & Orta Etki \\
\hline $\mathrm{YK} \leftarrow \mathrm{S}$ & $* * *$ &, 329 & Orta Etki \\
\hline $\mathrm{KK} \leftarrow \mathrm{S}$ & $* * *$ &, 407 & Orta Etki \\
\hline $\mathrm{PÇYG \leftarrow C \zeta}$ & $* * *$ &,- 258 & Orta Etki \\
\hline $\mathrm{YK} \leftarrow C \zeta$ &, 003 &,- 171 & Küçük Etki \\
\hline $\mathrm{KK} \leftarrow C \zeta$ & $* * *$ &,- 354 & Orta Etki \\
\hline
\end{tabular}

S=Standartlar, Ç=Çelişki, PÇYG=Problem Çözme Yeteneğine Güven, YK=Yaklaşma-Kaçınma, KK=Kişisel Kontrol.

Tablo 5'e göre standartlar problem çözme yeteneğine güveni $(p<0,05 ; \beta=, 341)$, yaklaşmakaçınmayı $(p<0,05 ; \beta=, 329)$ ve kişisel kontrolü $(p<0,05 ; \beta=, 407)$ doğrusal yönde etkilemektedir. Yani standartlardaki bir birimlik değişim problem çözme yeteneğine güvende 0,341, yaklaşmakaçınmada 0,329 ve kişisel kontrolde 0,407 oranında değişime neden olmaktadır. Çelişki problem çözme yeteneğine güveni $(p<0,05 ; \beta=-, 258)$, yaklaşma-kaçınmayı $(p<0,05 ; \beta=-, 171)$ ve kişisel kontrolü $(p<0,05 ; \beta=-, 354)$ ters yönde etkilemektedir. Yani çelişkideki bir birimlik değişim problem çözme yeteneğine güvende $-0,258$, yaklaşma-kaçınmada $-0,171$ ve kişisel kontrolde 0,354 oranında değişime neden olmaktadır.

Etki büyüklükleri değerlendirilirken Kline'ın (2010) önerdiği ölçütler göz önüne alınmıştır. Buna göre standartların problem çözme yeteneğine güven, yaklaşma-kaçınma ve kişisel kontrol 
üzerinde orta düzey bir etkisi görülmektedir. Çelişkinin ise problem çözme yeteneğine güven ve kişisel kontrol üzerindeki etkisi orta düzeyde iken, yaklaşma-kaçınma üzerindeki etkisi küçük düzeyde görülmektedir.

Araştırmanın ikinci modelinde mükemmeliyetçiliğin duygusal zekâ üzerinde, duygusal zekânın problem çözme becerisi üzerinde etkisinin olup olmadığı ve duygusal zekânın mükemmeliyetçilik ve problem çözme becerisi ilişkisinde aracı bir etkiye sahip olup olmadığı test edilmiş olup, model Şekil 3'te gösterilmiştir.

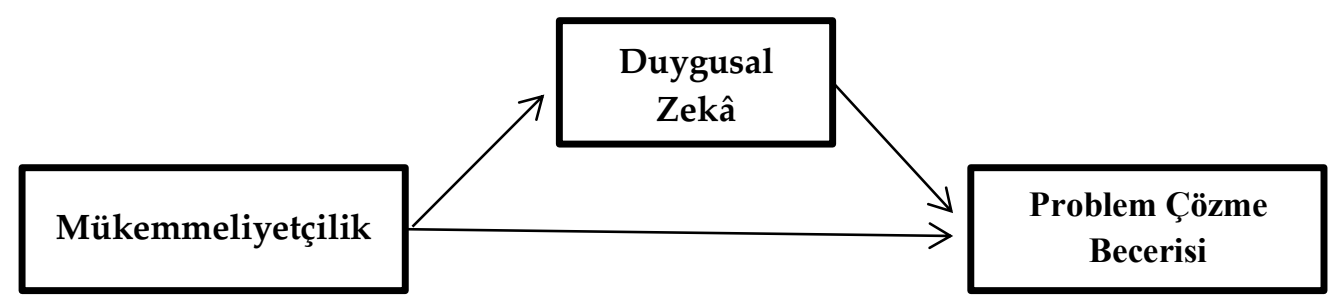

Şekil 3. Aracılık Etkisinin Test Edilmesi İçin Kurulan İkinci Model

Aracılık etkisinin test edilmesi için kurulan ikinci modele ilişkin analiz sonuçlarına göre uyum indeks değerleri (x2/sd=1,881, NFI=0,902, NNFI(TLI) $=0,902, \mathrm{IFI}=0,912, \mathrm{CFI}=0,901$, RMSEA $=0,046$, GFI=0,855, AGFI=0,823) önerilen modelin veri ile uyumlu ve kabul edilebilir olduğunu göstermektedir. Yani bu sonuçlara göre, kurulan modelin uygun olduğunu söylemek mümkündür. Dolayısıyla aracılık etkisinin test edilmesi için oluşturulan ikinci modelin veri uyumu sağlanmaktadır.

İkinci modele ilişkin uyum tespit edildikten sonra değişkenler arasındaki ilişkilerin anlamlılığ kontrol edilmiştir. Anlamlılık kontrol edildikten sonra değişkenlere ilişkin Beta değerlerine bakılmıştır. İkinci modele ilişkin anlamlılık ve Beta değerleri Tablo 6' da görülmektedir.

Tablo 6'ya göre standartların problem çözme yeteneğine güven ve yaklaşma-kaçınma üzerinde istatistiksel olarak anlamlı bir etkisi tespit edilememiştir $(p>0,05)$. Ancak standartlar kişisel kontrolü $(\mathrm{p}<0,05 ; \beta=, 159)$ doğrusal yönde etkilemektedir. Yani standartlardaki bir birimlik değişim kişisel kontrolde 0,159 oranında değişime neden olmaktadır. Çelişkinin problem çözme yeteneğine güven ve yaklaşma-kaçınma üzerinde istatistiksel olarak anlamlı bir etkisi tespit edilememiştir ( $p>0,05)$. Ancak çelişki kişisel kontrolü $(p<0,05 ; \beta=-, 204)$ ters yönde etkilemektedir. Yani çelişkideki bir birimlik değişim kişisel kontrolde $-0,204$ oranında değişime neden olmaktadır. Standartlar bireysel duygusal değerlendirmeyi $(p<0,05 ; \beta=, 218)$, başkalarının duygularını değerlendirmeyi $(p<0,05 ; \beta=, 231)$, duyguların kullanımını $(p<0,05 ; \beta=, 510)$ ve duyguları düzenlemeyi $(p<0,05 ; \beta=, 281)$ doğrusal yönde etkilemektedir. Yani standartlardaki bir birimlik değişim bireysel duygusal değerlendirmede 0,218, başkalarının duygularını değerlendirmede 0,231 , duyguların kullanımında 0,510 ve duyguları düzenlemede 0,281 oranında değişime neden olmaktadır. Çelişki bireysel duygusal değerlendirmeyi $(p<0,05 ; \beta=-$ ,130), duyguların kullanımını $(p<0,05 ; \beta=-, 295)$ ve duyguları düzenlemeyi $(p<0,05 ; \beta=-, 173)$ ters yönde etkilemektedir. Yani çelişkideki bir birimlik değişim bireysel duygusal değerlendirmede 0,130, duyguların kullanımında $-0,295$ ve duyguları düzenlemede $-0,173$ oranında değişime neden olmaktadır. Ancak çelişkin başkalarının duygularını değerlendirme üzerinde istatistiksel olarak anlamlı bir etkisi tespit edilememiştir $(p>0,05)$. Benzer şekilde bireysel duygusal değerlendirmenin problem çözme yeteneğine güven, yaklaşma-kaçınma ve kişisel kontrol üzerinde istatistiksel olarak anlamlı bir etkisi tespit edilememiştir $(p>0,05)$. Başkalarının duygularını değerlendirme problem çözme yeteneğine güveni $(p<0,05 ; \beta=, 168)$ ve yaklaşma- 
kaçınmayı $(p<0,05 ; \beta=, 160)$ doğrusal yönde etkilemektedir. Yani başkalarının duygularını değerlendirmedeki bir birimlik değişim problem çözme yeteneğine güvende 0,168 ve yaklaşmakaçınmada 0,160 oranında değişime neden olmaktadır. Ancak başkalarının duygularını değerlendirmenin kişisel kontrol üzerinde istatistiksel olarak anlamlı bir etkisi tespit edilememiştir ( $p>0,05)$. Duyguların kullanımı problem çözme yeteneğine güveni $(p<0,05 ; \beta=, 557)$, yaklaşma-kaçınmayı $(p<0,05 ; \beta=, 479)$ ve kişisel kontrolü $(p<0,05 ; \beta=, 494)$ doğrusal yönde etkilemektedir. Yani duyguların kullanımındaki bir birimlik değişim problem çözme yeteneğine güvende 0,557, yaklaşma-kaçınmada 0,479 ve kişisel kontrolde 0,494 oranında değişime neden olmaktadır. Duyguları düzenleme problem çözme yeteneğine güveni doğrusal yönde etkilerken $(p<0,05 ; \beta=, 148)$, yaklaşma-kaçınmayı $(p<0,05 ; \beta=-, 111)$ ters yönde etkilemektedir. Yani duyguları düzenlemedeki bir birimlik değişim problem çözme yeteneğine güvende 0,148 ve yaklaşmakaçınmada -,111 oranında değişime neden olmaktadır. Ancak duyguları düzenlemenin kişisel kontrol üzerinde istatistiksel olarak anlamlı bir etkisi tespit edilememiştir ( $p>0,05)$.

Tablo 6. İkinci Modele İlişkin Yol Katsayıları ve Etki Büyüklükleri

\begin{tabular}{|c|c|c|c|}
\hline Etkilenen $\leftarrow$ Etkileyen & $\mathrm{p}$ & Beta $(\beta)$ & Etki Büyüklüğü \\
\hline $\mathrm{PÇYG \leftarrow S}$ & ,497 &,- 049 & - \\
\hline $\mathrm{YK} \leftarrow \mathrm{S}$ & 456 & ,056 & - \\
\hline $\mathrm{KK} \leftarrow \mathrm{S}$ & ,032 & 159 & Küçük Etki \\
\hline $\mathrm{PÇYG} \leftarrow$ Ç & ,330 &,- 058 & - \\
\hline $\mathrm{YK} \leftarrow \mathrm{C}$ & ,755 &,- 020 & - \\
\hline $\mathrm{KK} \leftarrow$ Ç & $* * *$ &,- 204 & Orta Etki \\
\hline$B \dot{R} D D \leftarrow S$ & $* * *$ & ,218 & Orta Etki \\
\hline BAŞDD $\leftarrow S$ & $* * *$ & 231 & Orta Etki \\
\hline DUYKUL $\leftarrow S$ & $* * *$ &, 510 & Büyük Etki \\
\hline DUYDÜZ $\leftarrow S$ & $* * *$ & ,281 & Orta Etki \\
\hline BİRDD $\leftarrow$ Ç & ,021 &,- 130 & Küçük Etki \\
\hline BAŞDD $\leftarrow$ Ç & 085 &,- 097 & - \\
\hline DUYKUL $\leftarrow$ Ç & $* * *$ &,- 295 & Orta Etki \\
\hline DUYDÜZ $\leftarrow C ̧$ & ,002 &,- 173 & Küçük Etki \\
\hline PÇYG $\leftarrow$ BİRDD & 496 & ,034 & - \\
\hline YK $\leftarrow$ BİRDD & ,931 & ,005 & - \\
\hline $\mathrm{KK} \leftarrow \mathrm{BİRDD}$ & ,379 &,- 046 & - \\
\hline PÇYG $\leftarrow$ BAŞDD & ,001 & ,168 & Küçük Etki \\
\hline $\mathrm{YK} \leftarrow \mathrm{BASSDD}$ & ,005 & , 160 & Küçük Etki \\
\hline $\mathrm{KK} \leftarrow \mathrm{BAŞDD}$ & ,091 &,- 090 & - \\
\hline PÇYG $\leftarrow$ DUYKUL & $* * *$ &, 557 & Büyük Etki \\
\hline YK $\leftarrow$ DUYKUL & $* * *$ & 479 & Orta Etki \\
\hline KK $\leftarrow$ DUYKUL & $* * *$ & ,494 & Orta Etki \\
\hline PÇYG $\leftarrow$ DUYDÜZ &, 005 & ,148 & Küçük Etki \\
\hline YK $\leftarrow$ DUYDÜZ & 049 &,- 111 & Küçük Etki \\
\hline KK $\leftarrow$ DUYDÜZ & 480 & ,038 & - \\
\hline
\end{tabular}

S=Standartlar, Ç=Çelişki, PÇYG=Problem Çözme Yeteneğine Güven, YK=Yaklaşma-Kaçınma, KK=Kişisel Kontrol, BİRDD=Bireysel Duygusal Değerlendirme, BAŞDD=Başkalarının Duygularını Değerlendirme, DUYKUL=Duyguların Kullanımı, DUYDÜZ=Duyguları Düzenleme. 
Etki büyüklükleri değerlendirilirken Kline'ın (2010) önerdiği ölçütler göz önüne alınmıştır. Buna göre standartların kişisel kontrol üzerindeki etkisi küçük düzeyde iken, çelişkinin kişisel kontrol üzerindeki etkisi orta düzeydedir. Standartların bireysel duygusal değerlendirme, başkalarının duygularını değerlendirme ve duyguları düzenleme üzerinde orta düzey bir etkisi görülürken, duyguların kullanımı üzerinde büyük düzey bir etkisi görülmektedir. Çelişkinin bireysel duygusal değerlendirme ve duyguları düzenleme üzerindeki etkisi küçük düzeyde iken, duyguların kullanımı üzerindeki etkisi orta düzeydedir. Başkalarının duygularını değerlendirmenin problem çözme yeteneğine güven ve yaklaşma-kaçınma üzerindeki etkisi küçük düzeydedir. Duyguların kullanımının problem çözme yeteneğine güven üzerinde büyük düzey bir etkisi görülürken, yaklaşma-kaçınma ve kişisel kontrol üzerinde orta düzey bir etkisi görülmektedir. Duyguları düzenlemenin problem çözme yeteneğine güven ve yaklaşmakaçınma üzerindeki etkisi ise küçük düzeydedir. Tablo 7 'de ikinci modele ilişkin açıklanan varyans oranlarına yer verilmiştir.

Tablo 7. İkinci Modele İlişkin Açıklanan Varyans Oranları

\begin{tabular}{lc}
\hline Boyutlar & Açılanan Varyans Oranı \\
\hline Problem Çözme Yeteneğine Güven &, 426 \\
\hline Yaklaşma-Kaçınma &, 304 \\
\hline Kişisel Kontrol &, 440 \\
\hline Bireysel Duygusal Değerlendirme &, 064 \\
\hline Başkalarının Duygularını Değerlendirme &, 063 \\
\hline Duyguların Kullanımı &, 347 \\
\hline Duyguları Düzenleme &, 109 \\
\hline
\end{tabular}

Tablo 7 incelendiğinde mükemmeliyetçiliğin problem çözme becerisinin ve duygusal zekânın alt boyutlarını ne oranda açıkladığına ilişkin açıklanan varyans oranı görülmektedir. Mükemmeliyetçiliğin problem çözme yeteneğine güvenin \%42'sini, yaklaşma-kaçınmanın \%30'unu ve kişisel kontrolün \%44'ünü açıladığı görülmektedir. Yine mükemmeliyetçilik bireysel duygusal değerlendirmenin \%06'sını, başkalarının duygularını değerlendirmenin $\% 06$ 'sını, duyguların kullanımının \%34'ünü ve duyguları düzenlemenin \%10'unu açıklamaktadır.

Araştırma kapsamında mükemmeliyetçilik problem çözme becerisi ilişkisinde duygusal zekânın aracı rolünü tespit edebilmek için toplam, doğrudan ve dolaylı etkilere bakılmıştır. Bu nedenle standardize edilmiş toplam etkiler, standardize edilmiş doğrudan etkiler, standardize edilmiş dolaylı etkiler ve bootstrapping güven aralığına ilişkin bilgiler Tablo 8'de detaylandırılmıştır.

Tablo 8 incelendiğinde toplam, doğrudan, dolaylı etkiler ve dolaylı etkiye ilişkin bootstrapping güven aralığı görülmektedir. Toplam etki ve doğrudan etki arasındaki farka bakıldığında ise dolaylı etkinin büyüklüğü görülmektedir. Bu bağlamda standartların problem çözme yeteneğine güven $(\beta=, 372)$, yaklaşma-kaçınma $(\beta=, 251)$ ve kişisel kontrol $(\beta=, 232)$ üzerine etkisinde duygusal zekâ aracı etkiye sahiptir. Aynı şekilde çelişkinin problem çözme yeteneğine güven $(\beta=-, 211)$, yaklaşma-kaçınma $(\beta=-, 138)$ ve kişisel kontrol $(\beta=-, 138)$ üzerine etkisinde duygusal zekâ aracı etkiye sahiptir. 
Tablo 8. Toplam, Doğrudan, Dolaylı Etkiler ve Bootstrapping Güven Aralığ1

\begin{tabular}{|c|c|c|c|c|c|c|c|c|c|c|}
\hline \multirow{3}{*}{ PÇYG } & \multicolumn{2}{|c|}{$\begin{array}{l}\text { Toplam } \\
\text { Etkiler }\end{array}$} & \multicolumn{2}{|c|}{$\begin{array}{l}\text { Doğrudan } \\
\text { Etkiler }\end{array}$} & \multicolumn{2}{|c|}{$\begin{array}{l}\text { Dolaylı } \\
\text { Etkiler }\end{array}$} & \multicolumn{4}{|c|}{$\begin{array}{l}\text { Bootstrapping } \\
\text { (Alt-Üst Sinur) }\end{array}$} \\
\hline & $S$ & Ç & $S$ & Ç & $S$ & Ç & & & & \\
\hline & ,323 &,- 269 &,- 049 &,- 058 & ,372 &,- 211 & ,222 & ,765 &,- 437 &,- 101 \\
\hline YK & ,307 &,- 158 & ,056 &,- 020 & 251 &,- 138 & ,111 & ,602 &,- 338 &,- 049 \\
\hline KK & 391 &,- 341 & ,159 &,- 204 & 232 &,- 138 & , 108 & , 475 &,- 281 &,- 056 \\
\hline BİRDD & ,218 &,- 130 & ,218 &,- 130 & ,000 & ,000 & & & & \\
\hline BAŞDD & 231 &,- 097 & 231 & -,097 & ,000 & ,000 & & & & \\
\hline DUYKUL & ,510 &,- 295 & ,510 &,- 295 & ,000 & ,000 & & & & \\
\hline DUYDÜZ & 281 &,- 173 & 281 &,- 173 & ,000 & ,000 & & & & \\
\hline
\end{tabular}

S=Standartlar, Ç=Çelişki, PÇYG=Problem Çözme Yeteneğine Güven, YK=Yaklaşma-Kaçınma, KK=Kişisel Kontrol, BİRDD=Bireysel Duygusal Değerlendirme, BAŞDD=Başkalarının Duygularını Değerlendirme, DUYKUL=Duyguların Kullanımı, DUYDÜZ=Duyguları Düzenleme.

Duygusal zekânın mükemmeliyetçilik ve problem çözme becerisi ilişkisinde aracı etkiye sahip olmasına ilişkin yapılması gereken son işlem ise aracı etkinin anlamlı olup olmadığının test edilmesidir. Bu araştırma kapsamında aracı modele ait dolaylı etkilerin anlamlı olup olmadığını belirlemek amaciyla 5.000 örnekleme yoluyla gerçekleştirilen bootstrapping yöntemi sonucunda bootstrapping katsayısı ve \%95 güven aralığı ile çalışılmıştır. Bootstrapping yönteminde güven aralıklarının alt ve üst sınırı sıfırı içermediği zaman incelenen etkinin anlamlı bir etki olduğu anlaşılmaktadır (Preacher ve Hayes, 2008). Tablo 8'de dolaylı etkiye ilişkin güven aralığının alt ve üst sınırı görülmektedir.

Bootstrapping sonuçlarına göre, standartların problem çözme yeteneğine güven (alt sınır=,222; üst sınır=,765), yaklaşma-kaçınma (alt sınır=111; üst sınır=,602) ve kişisel kontrol (alt sınır=,108; üst sınır=,475) üzerine etkisinde duygusal zekânın dolaylı etkisinin olduğu saptanmıştır. Benzer şekilde çelişkinin problem çözme yeteneğine güven (alt sınır=-,437; üst sınır=-,101), yaklaşmakaçınma (alt sınır=-,338; üst sınır=-,049) ve kişisel kontrol (alt sınır=-,281; üst sınır=-,056) üzerine etkisinde duygusal zekânın dolaylı etkisinin olduğu tespit edilmiştir. Bootstrapping alt ve üst güven aralığı değerlerinin sıfır değerini kapsamadığı görülmektedir. Dolayısıyla duygusal zekânın aracılık etkisinin anlamlı olduğu sonucuna ulaşılmıştır.

Genel olarak bakıldığında duygusal zekânın mükemmeliyetçilik ve problem çözme becerisi ilişkisindeki dolaylı etkisinin anlamlı olduğu tespit edilmiştir. Bu sonuçlar, mükemmeliyetçilik ve problem çözme becerisi arasındaki ilişkide duygusal zekânın aracılık etkisinin olduğunu göstermektedir.

\section{TARTIŞMA, SONUÇ ve ÖNERİLER}

Mükemmeliyetçiliğin problem çözme becerisine etkisinde duygusal zekânın aracı rolünü test edebilmek için dört ana hipotez belirlenmiştir. Hipotezlerin desteklenip desteklenmediğini ortaya çıkarabilmek için araştırmanın sonuçları istatistik programlarına yüklenmiş ve uygun analiz teknikleri kullanılarak analiz edilmiştir. Araştırma bulguları teorik ve pratik katkılar dikkate alınarak aşağıda tartışılmıştır.

Belirlenen $\mathrm{H}_{1}$ hipotezi ile mükemmeliyetçiliğin problem çözme becerisi üzerinde anlamlı bir etkisinin olup olmadığ değişkenleri alt boyutları ile birlikte ele alınarak ölçülmüş ve analize tabi tutulmuştur. Yapılan analizler sonucunda standartların problem çözme yeteneğine güven, yaklaşma-kaçınma ve 
kişisel kontrol üzerinde anlamlı bir etkisi ortaya çıkmıştır. Çelişkinin problem çözme yeteneğine güven ve kişisel kontrol üzerinde anlamlı bir etkisi görülürken, çelişkinin yaklaşma-kaçınma üzerinde anlamlı bir etkisinin olmadığ ${ }_{1}$ sonucuna ulaşılmıştır. Bu nedenle $\mathrm{H}_{1}$ ana hipotezi kısmen kabul edilmiştir. Belirlenen birinci ana hipotez ile ilgili elde edilen sonuçların alanyazınla da uyumlu olduğu görülmektedir (Flett vd., 1996; Chang, 2002; Berberena, 2009; Besser vd., 2010; Özkara, 2015). Yani mükemmeliyetçilik profesyonel turist rehberlerinin problem çözme becerilerini olumlu ya da olumsuz yönde etkileyebilmektedir. Yapılan araştırmada ise olumlu mükemmeliyetçilik problem çözme becerisini pozitif yönde etkilerken, olumsuz mükemmeliyetçilik problem çözme becerisini negatif yönde etkilemektedir. Bir başka deyişle, olumlu mükemmeliyetçiliğe sahip olan profesyonel turist rehberlerinin problem çözme becerileri daha yüksek olurken, olumsuz mükemmeliyetçiliğe sahip rehberlerin problem çözme becerileri ise düşük olabilmektedir.

Belirlenen $\mathrm{H}_{2}$ hipotezi ile mükemmeliyetçiliğin duygusal zekâ üzerinde anlamlı bir etkisinin olup olmadığı test edilmiştir. Mükemmeliyetçilik ve duygusal zekâ değişkenleri alt boyutları ile birlikte ele alınarak ölçülmüş ve analize tabi tutulmuştur. Yapılan analizler sonucunda standartların bireysel duygusal değerlendirme, başkalarının duygularını değerlendirme, duyguların kullanımı ve duyguları düzenleme üzerinde anlamlı bir etkisi ortaya çıkmıştır. Çelişkinin bireysel duygusal değerlendirme, duyguların kullanımı ve duyguları düzenleme üzerinde anlamlı bir etkisi görülürken, çelişkinin başkalarının duygularını değerlendirme üzerinde anlamlı bir etkisinin olmadığı sonucuna ulaşılmıştır. Bu nedenle $\mathrm{H}_{2}$ ana hipotezi de kısmen kabul edilmiştir. Belirlenen ikinci ana hipotez ile ilgili elde edilen sonuçların alanyazınla da uyumlu olduğu görülmektedir (Chan, 2009; Eum ve Rice, 2011; Gong vd., 2017; PerroneMcGovern vd., 2017). Yapılan araştırmada olumlu mükemmeliyetçilik duygusal zekâyı pozitif yönde etkilerken, olumsuz mükemmeliyetçilik duygusal zekâyı negatif yönde etkilemektedir. Yani, olumlu mükemmeliyetçiliği yüksek olan profesyonel turist rehberlerinin duygusal zekâ düzeyleri de yüksek olurken, olumsuz mükemmeliyetçiliği yüksek olan rehberlerin ise duygusal zekâ düzeyleri düşük olabilmektedir.

Belirlenen $\mathrm{H}_{3}$ hipotezi ile duygusal zekânın problem çözme becerisi üzerinde anlamlı bir etkisinin olup olmadığı test edilmiştir. Duygusal zekâ ve problem çözme becerisi değişkenleri alt boyutları ile birlikte ele alınarak ölçülmüş ve analize tabi tutulmuştur. Yapılan analizler sonucunda bireysel duygusal değerlendirmenin problem çözme yeteneğine güven, yaklaşma-kaçınma ve kişisel kontrol üzerinde herhangi bir anlamlı etkisinin olmadığı sonucu ortaya çıkmıştır. Başkalarının duygularını değerlendirmenin problem çözme yeteneğine güven ve yaklaşmakaçınma üzerinde anlamlı bir etkisi görülürken, başkalarının duygularını değerlendirmenin kişisel kontrol üzerinde anlamlı bir etkisinin olmadığı sonucuna ulaşılmıştır. Duyguların kullanımının problem çözme yeteneğine güven, yaklaşma-kaçınma ve kişisel kontrol üzerinde anlamlı bir etkisinin olduğu sonucu ortaya çıkmıştır. Duyguları düzenlemenin problem çözme yeteneğine güven üzerinde anlamlı bir etkisi görülürken, duyguları düzenlemenin yaklaşmakaçınma ve kişisel kontrol üzerinde anlamlı bir etkisinin olmadığı sonucuna ulaşılmıştır. Bu nedenle $\mathrm{H}_{3}$ ana hipotezi de kısmen kabul edilmiştir. Belirlenen üçüncü ana hipotez ile ilgili elde edilen sonuçların alanyazınla da uyumlu olduğu görülmektedir (İşmen, 2001; Rahim ve Minors, 2003; Güler, 2006; Yerli, 2009; Azeez ve Omolade, 2010; Y1lmaz Karabulutlu vd., 2011; Şahin, 2015; Hasnah vd., 2018). Yapılan araştırmada duygusal zekâ problem çözme becerisini pozitif yönde etkilemektedir. Bir başka deyişle, duygusal zekâ düzeyleri yüksek olan profesyonel turist rehberlerinin problem çözme becerileri de yüksek olurken, duygusal zekâ düzeyleri düşük olan rehberlerin problem çözme becerileri de düşük olabilmektedir.

Belirlenen $\mathrm{H}_{4}$ hipotezi ile mükemmeliyetçiliğin problem çözme becerisine etkisinde duygusal zekânın aracı rolünün olup olmadığı test edilmiştir. Yapılan analizler sonucunda $\mathrm{H}_{4}$ ana hipotezi 
kabul edilmiştir. Yani dördüncü hipotez mükemmeliyetçilik, problem çözme becerisi ve duygusal zekâ arasında ilişki olduğunu ve duygusal zekânın mükemmeliyetçilik ve problem çözme becerisi ilişkisinde aracı role sahip olduğunu göstermiştir. Dolayısıyla araştırmanın amacı doğrultusunda öngörülen sonuçlara ulaşılmıştır.

Araştırmanın teorik katkılarının yanı sıra seyahat acentelerine, turistlere ve profesyonel turist rehberlerine yani uygulamacılara katkıları da mevcuttur. Turizm sektörünün önemli paydaşlarından biri olan seyahat acentelerinin önem verdikleri konulardan biri turist memnuniyetidir. Turistler, tatilleri sırasında herhangi bir problem yaşamak istememektedirler. Buna bağlı olarak acenteler bilgili ve deneyimli profesyonel turist rehberlerini tercih etmektedirler. Böylelikle tur esnasında yaşanacak herhangi bir olumsuzluk ya da problem ihtimali ortadan kalkmaktadır. Bu noktada profesyonel turist rehberlerine büyük bir rol düşmektedir. Çünkü turist, seyahati boyunca rehber ile vakit geçirmektedir. Bu nedenle profesyonel turist rehberlerinin problem çözme becerisinin oldukça yüksek olması beklenmektedir. Problem çözme becerisini etkileyen birçok faktör bulunmaktadır. Araştırma kapsamında ele alınan mükemmeliyetçilik ve duygusal zekâ bu faktörler arasında yer almaktadır. Profesyonel turist rehberlerinin olumlu mükemmeliyetçilik düzeyleri arttıkça problem çözme becerileri de artmaktadır. Yine olumlu mükemmeliyetçilik düzeyinin yüksek olması duygusal zekâ seviyesini arttırmakta ve bu sonuç problem çözme becerisine olumlu yansımaktadır. Tüm bunlar profesyonel turist rehberlerinin daha iyi hizmet sunmaya gönüllü olmalarına katkıda bulunmaktadır. Böylelikle acenteler aracılığı ile gerçekleştirilen turların kalitesi artmaktadır. Bu noktada hizmeti alan turistlerin memnun kalmaları oldukça önemlidir. Hizmeti veren profesyonel turist rehberlerinin ise olumlu mükemmeliyetçi kişilik özelliğine ve yüksek duygusal zekâya sahip olmaları yaşanan problemlerin kolaylıkla çözülmesini kolaylaştırmaktadır. Böylelikle sadık turistler oluşmaktadır. Ağızdan ağıza iletişim ile birlikte acenteye geri dönüşler olumlu olmakta ve acentenin imajına olumlu etki etmektedir.

Ulaşılan sonuçlar doğrultusunda gelecekte yapılacak araştırmalara birtakım önerilerde bulunulmuştur. Profesyonel turist rehberleri için problem çözme becerisi oldukça önemlidir. Problem çözme becerisini etkileyen en önemli değişkenlerden biri mükemmeliyetçilik bir diğeri ise duygusal zekâdır. Araştırmaya konu olan bu değişkenlerin tecrübeye bağlı olarak değiştiği yapılan analizler sonucunda bulgulanmıştır. Bu nedenle mesleğe yeni başlayan profesyonel turist rehberleri, problemleri etkili çözmede yeteri kadar olumlu mükemmeliyetçiliğe ve yüksek duygusal zekâya sahip olmamaktadır. Bu sonuçlardan hareketle üniversitelerde turist rehberliği programlarında öğrenim gören rehber adaylarının mesleğe başladıklarında karşılaştıkları sorunları çözebilmeleri için mükemmeliyetçilik, duygusal zekâ gibi konularda eğitim almaları önerilmektedir. İlgili eğitimlerin sadece üniversitelerde değil aynı zamanda ulusal ve uluslararası çeşitli turizm kuruluşları tarafından da verilmesi önerilmektedir. Çünkü duygusal zekâ sonradan geliştirilebilen bir zekâ türüdür. Olumlu mükemmeliyetçiliğe sahip profesyonel turist rehberleri sahip oldukları yüksek duygusal zekâyla, karşılaştıkları problemleri sağlıklı bir şekilde çözebileceklerdir.

Araştırmanın evrenini profesyonel turist rehberleri oluşturmaktadır. Başka çalışmalarda otel yöneticilerinin, otel çalışanlarının, seyahat acentesi yöneticilerinin, seyahat acentesi çalışanlarının veya turizmle ilgili diğer paydaşların araştırmanın evreni olarak belirlenmesi önerilmektedir. Başka evrenler üzerinde uygulama yapılması farklı sonuçların çıkmasına olanak verecektir.

Yapılan araştırmada duygusal zekânın mükemmeliyetçilik ve problem çözme becerisi ilişkisinde aracı etkisine bakılmıştır. Daha sonraki çalışmalarda düzenleyici etkiye bakılması önerilmektedir. Yapılan görüşmeler neticesinde duygusal zekânın olumlu mükemmeliyetçiliği pozitif yönde, olumsuz mükemmeliyetçiliği ise negatif yönde etkileyebileceği kanısına varılmıştır. Böylelikle mükemmeliyetçilik profesyonel turist rehberlerinin problem çözme 
becerilerini olumlu veya olumsuz yönde etkileyebilmektedir. Dolayısıyla bu değişkenlerin arasındaki yoğun ilişki göz önüne alındığında düzenleyici etkinin de test edilebileceği düşünülmektedir.

Yapılan araştırma sonucunda problem çözme becerisi üzerinde mükemmeliyetçi kişilik özelliğinin etkili olduğu saptanmıştır. Bu nedenle diğer kişilik türlerinin de problem çözme becerisini etkilemesi muhtemel görünmektedir. Daha sonraki çalışmalarda mükemmeliyetçilik, problem çözme becerisi ve duygusal zekânın proaktif kişilik, kontrol odağı vb. diğer kişilik türleri ile de çalışılabileceği düşünülmektedir.

\section{KAYNAKÇA}

Ahipaşaoğlu, S. (2006). Turizmde Rehberlik. Ankara: Gazi Kitabevi.

Anderson, J. R. (1980). Cognitive Psychology and Its Implications. New York: Worth Publishers.

Antony, M. M. and McCabe, R. E. (2005). Perfectionism, Encyclopedia of Cognitive Behavior Therapy, 273-277.

Arlı, D., Altunay, E. ve Yalçınkaya, M. (2011). Öğretmen Adaylarında Duygusal Zekâ, Problem Çözme ve Akademik Başarı İlişkisi, Akademik Bakış Dergisi, 25: 1-23.

Azeez, R. O. and Omolade, M. A. (2010). Joint and Relative Effect of Emotional Intelligence, Problem Solving Skills and Gender on Decision Making Abilities of Secondary School Administrators, International Journal of Research in Education, 2(8): 139-146.

Berberena, S. (2009). Investigating the Relation Between Dimensions of Perfectionism and Social Problem-solving, Yayımlanmamış Yüksek Lisans Tezi, Central Connecticut Devlet Üniversitesi, Connecticut.

Besser, A., Flett, G. L. and Hewitt, P. L. (2010). Perfectionistic Self-presentation and Trait Perfectionism in Social Problem-solving Ability and Depressive Symptoms, Journal of Applied Social Psychology, 40(8): 2121-2154.

Burns, D. D. (1980). Feeling Good: The New Mood Therapy. New York: New American Library.

Chan, D. W. (2009). Dimensionality and Typology of Perfectionism: The Use of The Frost Multidimensional Perfectionism Scale with Chinese Gifted Students in Hong Kong, Gifted Child Quarterly, 53(3): 174-187.

Chang, E. C. (2002). Examining the Link Between Perfectionism and Psychological Maladjustment: Social Problem-solving as A Buffer, Cognitive Therapy and Research, 26(5): 581-595.

Çarkıt, E. ve Yalçın, S. B. (2018). Üniversite Öğrencilerinin Düşünce Hataları ve Duyguları İfade Etmelerinin Mükemmeliyetçilik Tutumların Yordaması, Sakarya University Journal of Education, 8(1): 195-210.

D'Zurilla, T. J. and Goldfried, M. R. (1971). Problem Solving Behavior Modification, Journal of Abnormal Psychology, 78(1): 107-126.

Eum, K. and Rice, K. G. (2011). Test Anxiety, Perfectionism, Goal Orientation and Academic Performance, Anxiety, Stress and Coping, 24(2): 167-178.

Flett, G. L. and Hewitt, P. L. (2002). Perfectionism and Maladjustment: An Overview of Theoretical, Definitional, and Treatment Issues, (Editör) Flett, G. L. and Hewitt, P. L.: Perfectionism: Theory, Research and Treatment içinde (ss.5-31) Washington: American Psychological Association. 
Flett, G. L., Hewitt, P. L., Blankstein, K. R., Solnik, M. and Van Brunschot, M. (1996). Perfectionism, Social Problem-solving Ability, and Psychological Distress, Journal of RationalEmotive and Cognitive-Behavior Therapy, 14(4): 245-275.

Fornell, C. and Larcker, D. F. (1981). Evaluating Structural Equation Models with Unobservable Variables and Measurement Error, Journal of Marketing Research, 18(1): 39-50.

Gong, X., Fletcher, K. L. and Paulson, S. E. (2017). Perfectionism and Emotional Intelligence: A Test of the 2x2 Model of Perfectionism, Personality and Individual Differences, 106: 71-76.

Güler, A. (2006). İlköğretim Okullarında Görev Yapan Öğretmenlerin Duygusal Zekâ Düzeyleri ile Problem Çözme Becerileri Arasındaki İlişkinin İncelenmesi, Yayımlanmamış Yüksek Lisans Tezi, Yeditepe Üniversitesi, İstanbul.

Gürbüz, S. (2019a). Sosyal Bilimlerde Aracı, Düzenleyici ve Durumsal Etki Analizleri. Ankara: Seçkin Yayıncilık.

Gürbüz, S. (2019b). AMOS ile Yapısal Eşitlik Modellemesi. Ankara: Seçkin Yayıncilık.

Hasnah, H., Hendra, D. A. and Hapsah, H. (2018). Correlation Between Emotional Intelligence and Problem-Solving Skill of Health Students of Faculty of Medicine Universitas Hasanuddin, Indonesian Contemporary Nursing Journal (ICON Journal), 3(1): 22-30.

Hayes, A. F. (2018). Introduction to Mediation, Moderation and Conditional Process Analysis. New York: The Guilford Press.

Heppner, P. P. (1987). Introduction: Broadening the Conceptualization of Problem Solving Within Career Planning, Journal of Career Development, 14(1): 3-7.

Heppner, P. and Peterson, C. H. (1982). The Development and Implications of a Personal Problem-Solving Inventory, Journal of Counseling Psychology, (29): 66-75.

İşmen, A. E. (2001). Duygusal Zekâ ve Problem Çözme, Atatürk Eğitim Fakültesi Ĕğitim Bilimleri Dergisi, 13: 111-124.

Kardaş, N., Anagün, Ş. S. ve Yalçınoğlu, P. (2014). Problem Çözme Envanterini İlköğretim Öğrencilerine Uyarlama Çalışması: Doğrulayıcı Faktör Analizi Sonuçları, Elektronik Sosyal Bilimler Dergisi, 13(51): 182-194.

Kaya, F. ve Birol, Z. N. (2018). Üniversite Öğrencilerinin Yalnızlık ve Mükemmeliyetçilik Düzeyleri Arasındaki İlişkide Duygusal Zekânın Aracılık Rolü, Kastamonu Eğitim Dergisi, 26(6): 1793-1802.

Kaya, F. ve Peker, A. (2016). Üniversite Öğrencilerinin Affetme ve Mükemmeliyetçilik Düzeyleri Arasındaki İlişki: Duygusal Zekânın Aracı Rolü, Gaziantep University Journal of Social Sciences, 15(4): 1086-1094.

Kline, R. B. (2010). Principles and Practice of Structural Equation Modeling. New York: The Guilford Press.

Mayer, J. D. and Salovey, P. (1993). The Intelligence of Emotional Intelligence, Intelligence, 17(4): 433-442.

Nazlı, S. (2013). Hemşirelerde Duygusal Zekâ ve Problem Çözme Becerileri Arasındaki İlişkinin İncelenmesi: Konya İli Örneği, Yayımlanmamış Yüksek Lisans Tezi, Selçuk Üniversitesi, Konya.

Ng, K. M., Wong, C., Zalaquett, C. P. and Bodenhorn, N. (2007). A Confirmatory Factor Analysis of The Wong and Law Emotional Intelligence Scale in A Sample of International College Students, International Journal for The Advancement of Counselling, 29(3-4): 173-185. 
Özkara, G. (2015). Mükemmeliyetçilik Düzeyleri ile Psikolojik İyi Olma Hali Arasındaki Illişki ve Problem Çözme Becerisine Etkisi, Yayımlanmamış Yüksek Lisans Tezi, Üsküdar Üniversitesi, İstanbul.

Perrone-McGovern, K., Simon-Dack, S., Esche, A., Thomas, C., Beduna, K., Rider, K. and Matsen, J. (2017). The Influence of Emotional Intelligence and Perfectionism on Error-related Negativity: An Event Related Potential Study, Personality and Individual Differences, 111: 65-70.

Preacher, K. J. and Hayes, A. F. (2008). Asymptotic and Resampling Strategies for Assessing and Comparing Indirect Effects in Multiple Mediator Models, Behavior Research Methods, 40(3): 879891.

Rahim, M. A. and Minors, P. (2003). Effects of Emotional Intelligence on Concern for Quality and Problem Solving, Managerial Auditing Journal, 18(2): 150-155.

Rehber Odalarına Göre Turist Rehberi Sayıları. http://www.tureb.org.tr (Erişim Tarihi: 3 Ağustos 2019).

Rice, K. G., Richardson, C. M. E. and Tueller, S. (2014). The Short Form of The Revised Almost Perfect Scale, Journal of Personality Assessment, 96(3): 368-379.

Sample Size Calculator. https://www.surveysystem.com (Erişim Tarihi: 3 Ağustos 2019).

Satıcı, B. (2018). Genç Yetişkinlerde Mükemmeliyetçilik ile Romantik İlişki Doyumu Arasında Duygusal Zekâ ve Bilinçli Farkındalığın Aracılık Rollerinin İncelenmesi, Yayımlanmamış Doktora Tezi, Yıldız Teknik Üniversitesi, İstanbul.

Smith, M. M., Saklofske, D. H. and Nordstokke, D. W. (2014). The Link Between Neuroticism and Perfectionistic Concerns: The Mediating Effect of Trait Emotional Intelligence, Personality and Individual Differences, 61(62): 97-100.

Şahin, H. (2015). Psikososyal Gelişim Temelli Eğitim Programının Anasınııına Devam Eden Çocukların Duygusal Zekâlarına ve Problem Çözme Becerilerine Etkisi, Yayımlanmamış Doktora Tezi, Gazi Üniversitesi, Ankara.

Tunca, M. M. (2004). Meslek Lisesi Öğretmenlerinin Duygusal Zekâları ile Problem Çözme Becerileri Arasındaki İlişkinin Araştırılması, Yayımlanmamış Yüksek Lisans Tezi, Marmara Üniversitesi, İstanbul.

Turan, H. (2010). Sınıf Öğretmenlerinin Yapılandırmacı Özellikleri ile Yaratıcı Düşünme, Problem Çözme Becerileri ve Eleştirel Düşünme Eğilimleri Arasındaki Açıklayıcı İlişkiler Örüntüsü, Yayımlanmamış Doktora Tezi, Yıldız Teknik Üniversitesi, İstanbul.

Yarcan, Ş. (2007). Profesyonel Turist Rehberliğinde Mesleki Etik Üzerine Kavramsal Bir Değerlendirme, Anatolia: Turizm Araştırmaları Dergisi, 18(1): 33-44.

Yerli, S. (2009). Illk ve Ortä̈ğretim Okullarındaki Yöneticilerin Duygusal Zekâ ve Problem Çözme Becerileri Arasındaki İlişki “İstanbul Anadolu Yakası Örneği”, Yayımlanmamış Yüksek Lisans Tezi, Maltepe Üniversitesi, İstanbul.

Yılmaz Karabulutlu, E., Yılmaz, S. ve Yurttaş, A. (2011). Öğrencilerin Duygusal Zekâ Düzeyleri ile Problem Çözme Becerileri Arasındaki İlişki, Psikiyatri Hemşireliği Dergisi, 2(2): 75-79. 